\title{
Evaluation of water, sucrose and minerals effective diffusivities during osmotic treatment of pork in sugar beet molasses
}

\author{
Milica R. Nićetin ${ }^{1}$, Lato L. Pezo ${ }^{2}$, Biljana Lj. Lončar ${ }^{1}$, Vladimir S. Filipović ${ }^{1}$, Danijela Z. Šuput ${ }^{1}$, \\ Snežana Zlatanović ${ }^{2}$, Biljana P. Dojčinović ${ }^{3}$ \\ ${ }^{1}$ University of Novi Sad, Faculty of Technology, 21000 Novi Sad, Serbia \\ ${ }^{2}$ University of Belgrade, Institute of General and Physical Chemistry, 11000 Beograd, Serbia \\ ${ }^{3}$ University of Belgrade, Institute of Chemistry, Technology and Metallurgy, 11000 Belgrade, Serbia
}

\begin{abstract}
Effective diffusivities of water, sucrose and minerals in osmotic treatment of pork cubes (M. triceps brachii) were calculated using Response Surface Methodology (RSM), with respect to temperature $\left(20,35\right.$ and $\left.50{ }^{\circ} \mathrm{C}\right)$ and concentration of sugar beet molasses, $(60$, 70 and 80 mass\%). The numerical solution of Fick's law for unsteady-state mass transfer in a perfect cube configuration was used to calculate the effective diffusivities of water, sucrose and minerals ( $\mathrm{Na}, \mathrm{K}, \mathrm{Ca}$ and $\mathrm{Mg}$ ). Zugarramurdi and Lupin's model was used to predict the equilibrium condition, which has shown to be appropriate for water loss and solute uptake during osmotic treatment. Effective diffusivity of water was found to be in the range of $6.95 \times 10^{-10}-8.03 \times 10^{-10} \mathrm{~m}^{2} \mathrm{~s}^{-1}$, the sucrose effective diffusivity was between $6.39 \times 10^{-10}$ and $8.25 \times 10^{-10} \mathrm{~m}^{2} \mathrm{~s}^{-1}$, while diffusivities for minerals $\left(\mathrm{m}^{2} \mathrm{~s}^{-1}\right)$ were in the range: $6.34 \times 10^{-10}-8.82 \times 10^{-10}$ for $\mathrm{Na}, 6.27 \times 10^{-10}-7.43 \times 10^{-10}$ for $\mathrm{K}, 6.44 \times 10^{-10}-8.94 \times 10^{-10}$ for $\mathrm{Ca}$ and $3.47 \times 10^{-10}-5.66 \times 10^{-10}$ for $\mathrm{Mg}$.
\end{abstract}

Keywords: pork, sugar beet molasses, osmotic treatment, diffusion, mass transfer.

SCIENTIFIC PAPER

UDC 637.5'64:544:664.151.2

Hem. Ind. 69 (3) 241-251 (2015)

doi: 10.2298/HEMIND131003037N

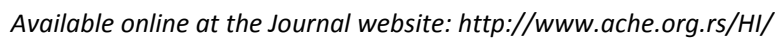

Physicochemical, sensory and technological properties of fresh meat are related with water content. Water is held in myofibrils, functional organelles of meat, but also it may exist in the intracellular space between myofibrils and sarcoplasm. The water content in meat depends on many factors, including the tissue itself and how the product is handled (time, temperature, treatments) [1-3].

Various meat preservation techniques usually include the introduction of high salt content, but nowadays consumers demand lower content of salt incurporated in the final product [4]. The interest of consumers in processed products with lower salt content is due to changes in the sensory preferences, but the main reason is the public concern as regards the high intake of sodium in the diet, which is known to increase the threat of cardiovascular damage [5]. The decrease of sodium content by partial substitution of sodium chloride with some other salts (like potassium chloride) is one of the most commonly used methods [6-8]. Nevertheless, there is little knowledge regarding the influence of the salts formulation on the kinetics and its influence on the salting step [6], as in the post-salting stage [9-12]. Recently, the mineral uptakes in pork

Correspondence: M.R. Nićetin, University of Novi Sad, Faculty of Technology, Bulevar Cara Lazara 1, 21000 Novi Sad, Serbia.

E-mail: milican85@live.com

Paper received: 3 October, 2013

Paper accepted: 12 March, 2014 brined with $\mathrm{NaCl}$ and K-lactate for obtaining low sodium meat products have been studied [13].

One of the preservation techniques for producing food with low water content and improved nutritional, sensorial and functional properties is osmotic treatment (OT). Osmotic treatment of foods presents some advantages compared with common drying techniques, such as minimizing heat damage to the color and flavor, inhibiting enzymatic browning and reducing energy costs. The use of OT as a complementary treatment in food processing, particularly prior to drying and freezing operations, reduces energy requirements of these processes. The technique aims to dehydrate food products by immersing them in hypertonic solution. The diffusion of water is accompanied by the simultaneous counter-diffusion of solute(s) from the osmotic solution into the meat tissue. Since the membrane responsible for osmotic transport is not perfectly selective, other solutes can also be leached into the osmotic solution $[2,14]$. Osmotic treatment of meat with salt solutions leads to complex phenomena, due to the dynamics of the actin-myosin-salt interactions which modify continuously the relative importance of mass transfer mechanisms.

The use of $\mathrm{NaCl}$ solutions during osmotic treatment provokes an increase of the muscles water holding capacity [3]. This is due to existing $\mathrm{Cl}^{-}$bonds with actin and myosin filaments, which increase negative charges, amplifying the repelling forces among the filaments, leading to muscle swelling. The direction of liquid flow 
in the intercellular spaces cannot be predicted only from the solution osmotic pressure because capillary forces play a major role on liquid flow. Osmotic treatment of raw meat with salt solutions leads to salt and water transfers, in the same directions or in countercurrent, depending on the osmotic solution concentration.

Different approaches have been proposed to explain the rates of mass transfer during osmotic treatment. The first is based on the tissue cellular structure, and the water transport is modeled according to the thermodynamics of irreversible processes $[3,15]$. Alternatively, the analytical solutions of Fick's second law of diffusion in non-stationary solids of different geometries can be used, allowing estimation of effective diffusion coefficients for water and solutes [16-24]. Rastogi et al. [14] reported Fickian unsteady-state diffusion as the most appropriate mechanism for the estimation of diffusion coefficients during osmo-concentration. However, the major drawback in the application of this law is the long experimental time required to attain equilibrium water loss.

Much work has been done in developing models to predict the mass-transfer kinetics of osmotic treatment, and some empirical and semi-empirical models have been proposed, [22-24]. These models correlate processing variables with water loss or solid gain without taking into account the underlying phenomena, and include multivariable regressions, response surface analysis, models derived from mass balances and others. Although mechanistic models give a description of the mass-transfer mechanism, the diffusion approach has a number of assumptions which are difficult to fulfill [1,25], and the effective diffusivity becomes an adjustable kinetic parameter that strongly depends on the experimental conditions and the physical properties of the meat [26]. Also, a cellular physiology approach depends on the knowledge of a large number of biophysical properties, such as membrane permeability and material properties, elastic modulus, void fraction and tortuosity, which are not always available $[2,15,25]$. On the other hand, even though the empirical and semi-empirical models that have been proposed in the literature give a reasonable fit to experimental data, their use is limited because they are only capable of representing data in conditions similar to those on which such models were developed, and they cannot take into account the process complexity [26, 27]. Andrade et al. [28] determined the effective diffusivity of sucrose and water during osmotic treatment of jenipapo based on analytical solution of Fick's second law. Schmidt et al. [26], studied the osmotic treatment kinetics of chicken breast cuts over a range of salt concentrations.
The use of a ternary system (water/sugar/salt) in the osmotic treatment of fruits has been studied by some researchers [29], and results have shown that higher rates of water loss are achieved when salt is added, even with solutions with low concentrations of solutes [30]. Most of the works published using the ternary solution provide only diffusion of solids, through determination of total solids by a gravimetric method, without analyzing separately the diffusion of the two solutes used in the solution, [29-31]. According to Bohuon et al. [32], the use of ternary solutions presents some advantages in the osmotic treatment process, without excessive over-sweetness or over-salting the product and without reaching the limits of saturation.

No studies relating to the osmotic treatment of pork cubes using sugar beet molasses were found in the current literature. Sugar beet molasses is an excellent medium for osmotic treatment, primarily due to the high dry matter (more than $80 \%$ ) and specific nutrient content. According to Sauvant et al. [33] and Grbeša [34] the concentrations of cations in sugar beet molasses are as follows: $3920 \mathrm{mg} \mathrm{K} / 100 \mathrm{~g}, 680-1300$ $\mathrm{mg} \mathrm{Na} / 100 \mathrm{~g}, 100 \mathrm{mg} \mathrm{Ca} / 100 \mathrm{~g}, 50-320 \mathrm{mg} \mathrm{Mg} / 100 \mathrm{~g}$ and $11.7 \mathrm{mg} \mathrm{Fe} / 100 \mathrm{~g}$. The specific chemical composition (approximately $51 \%$ sucrose, $1 \%$ raffinose, $0,25 \%$ glucose and fructose, $5 \%$ proteins, $6 \%$ betaine, $1,5 \%$ nucleosides, purine and pyramidine bases, organic acids and bases) and high content of solids (around $80 \%$ ) provide high osmotic pressure in the solution, so molasses appear to be an excellent osmotic medium $[35,36]$.

The current study intends to investigate the effects of sugar beet molasses concentration and immersion duration on the effective diffusivities of water and solutes during the osmotic treatment of pork. Sugar beet molasses as hypertonic solution is presented in this article because of high dry matter content and the enrichment of the food material in minerals and vitamins, which penetrate from molasses to the meat tissue. This investigation is also focused on finding the appropriate mathematical model for water loss, solid gain, sugars and minerals content, during OT of pork in sugar beet molasses. Simple regression models were proposed for calculation of the effective diffusivities of water, sucrose and minerals ( $\mathrm{Na}, \mathrm{K}, \mathrm{Ca}$ and $\mathrm{Mg}$ ) as function of the independent variables. The presented $\mathrm{Na}, \mathrm{K}, \mathrm{Ca}$ and $\mathrm{Mg}$ diffusivities during osmotic treatment of pork are presented for the first time, with no data to be compared in the literature.

\section{MATERIALS AND METHODS}

\section{Osmotic treatment}

Pork (M. triceps brachii, $24 \mathrm{~h}$ post mortem) was purchased just before use. Initial moisture content of 
the fresh meat was $72.83 \%$. Before the osmotic treatment, fresh meat was cut into cubes, dimension of nearly $1 \times 1 \times 1 \mathrm{~cm}^{3}$. Sugar beet molasses solution, with initial dry matter content of $85.04 \%$, was obtained from the sugar factory Pećinci, Serbia. Distilled water was used for dilution of solutions. Sugar beet molasses, was diluted to concentration of 60,70 and 80 mass\%. The sample to solution mass ratio was $1: 5$. The process was performed in laboratory jars at processing temperature of 20,35 and $50{ }^{\circ} \mathrm{C}$, with agitation on every $15 \mathrm{~min}$ under atmospheric pressure. The jars were kept in water bath, in order to retain samples at constant temperature. The osmotic treatment process was performed in a period of $0-5 \mathrm{~h}$. Samples were withdrawn from the osmotic solution at determined intervals of time (1, 3 and $5 \mathrm{~h}$ ), drained and dried with filter paper to remove adhering solution.

\section{Analytical determinations}

Dry matter content of the fresh and treated samples was determined by drying the material at 105 ${ }^{\circ} \mathrm{C}$ for $24 \mathrm{~h}$ in a heat chamber until constant weight was achieved (Instrumentaria Sutjeska, Croatia). All weight measurements were carried out in accordance to AOAC method [37]. Soluble solids content of the molasses solutions was measured using Abbe refractometer, (Carl Zeis Jenna, Germany) at $20^{\circ} \mathrm{C}$.

Mineral content of the raw pork and osmotic treated pork in the solution of sugar beet molasses was investigated. The combination of thermal treatment at 350 ${ }^{\circ} \mathrm{C}$, and wet acidic treatment at $160{ }^{\circ} \mathrm{C}$, was used for preparation of the samples. The dry samples were processed for minerals determination by wet digestion, where approx. $5 \mathrm{~g}$ each were weighed exactly to four decimal places, and transferred to vessels into which $4.5 \mathrm{ml} 65 \% \mathrm{HNO}_{3}$ and $10.5 \mathrm{ml} 35 \% \mathrm{HCl}$ were added. The treatments were repeated to obtain the white sediments that were dissolved in $0.07 \mathrm{M} \mathrm{HNO}_{3}$.

The content of minerals present in the corresponding solutions was determined by inductively coupled plasma optic emission spectrometry (ICP-OES). ICP-OES measurement was performed using Thermo Scientific ICAP 6500 Duo ICP (Thermo Fisher Scientific, Cambridge, United Kingdom) spectrometer equipped with RACID86 Charge Injector Device (CID) detector, standard glass concentric nebulizer, quartz torch, and alumina injector. Multi-elemental plasma standard solution (Multi-Element Plasma Standard Solution 4, Specpure $^{\circledR}, 1000 \mu \mathrm{g} / \mathrm{ml}$ ) certified by Alfa Aesar GmbH \& Co KG, Germany, was used to prepare calibration solutions for ICP-OES measurement. Measurements were performed on emission-lines Nal (818.326 nm), KI (766.490 $\mathrm{nm})$, Cal (431.865 nm) and $\mathrm{Mgl}(285.213 \mathrm{~nm})$. Value of radio frequency power of generator (RF) was $950 \mathrm{~W}$, and radial plasma view was used. Samples were analyzed in triplicate.
Sucrose and invert sugar content have been determined according to Luff-Schoorl method, based on $\mathrm{Cu}^{2+}$ reduction. By using this method, values of the total invert sugar (\%) and natural invert sugar (\%) content, could be determined. Based on this result, sucrose content (\%) in the fresh and dehydrated pork could be calculated. All experiments were repeated three times.

\section{Kinetic model}

The developed model, based on Fick's unsteadystate law of diffusion, determines the amount of water leaving the meat cube and the solutes diffusing into the meat as a function of time. According to Crank (1975), [38], Fick's second law solution for diffusion, for perfect cubes, assuming the diffusion to be perpendicular to the surface of the cube, is given by Eq. (1):

$$
X_{r}=\frac{x_{t}-x_{0}}{x_{e q}-x_{0}}=\frac{8}{\pi^{2}} \sum_{i=0}^{\infty} \exp \left(-i^{2} \pi^{2} D_{e f f} \frac{t}{L^{2}}\right)
$$

where $X_{r}$ denotes the dimensionless values of water loss, sucrose uptake or minerals uptake; $x_{t}, x_{0}$ and $x_{e q}$ are the moisture or the solute contents of a sample at treatment time $t$, at the outset and at equilibrium, respectively; $D_{\text {eff }}\left(\mathrm{m}^{2} \mathrm{~s}^{-1}\right)$ is the effective diffusivity, $L$ $(\mathrm{m})$ is the half thickness of the sample and $t(s)$ is the immersion time.

For long drying periods, Eq. (1) can be simplified to the first term of the series, and moisture ratio can be expressed in the logarithmic form:

$$
\begin{aligned}
& \ln X_{r}=\ln \frac{8}{\pi^{2}}-\left(\pi^{2} \frac{D_{e f f} t}{L^{2}}\right) \\
& D_{e f f}=D_{0} \exp \left(-\frac{E_{a}}{T R}\right)
\end{aligned}
$$

where the effect of temperature on effective diffusivity is expressed using Arrehnius type relationship. $E_{a}$ is the activation energy of moisture diffusion $\left(\mathrm{kJ} \mathrm{mol}^{-1}\right), D_{0}$ is the diffusivity value for infinite moisture content, and $R$ represent universal gas constant $\left(\mathrm{kJ} \mathrm{mol}^{-1}\right)$. $T$ is absolute process temperature (K).

Values of the effective diffusion coefficient $\left(D_{\text {eff }}\right)$ were obtained by non-linear regression analysis from Eq. (1), taking into account the first two terms of the series, as shown in Eq. (2) [39].

The following assumptions were used in the development of the model: samples of pork cubes are perfect cubes (dimension $1 \times 1 \times 1 \mathrm{~cm}^{3}$ ); initial water and solute concentrations in the pork cubes are uniform; the process is isothermal; simultaneous counter-current flows; the diffusion of water from the pork cubes and the diffusion of sugar and salt into the pork cubes are only considered; other mass transfers do not occur; 
shrinkage is neglected; external resistance to mass transfer is negligible.

The following mathematical model, with an exponential approach to the equilibrium value of moisture and solutes contents, was proposed by Zugarramurdi and Lupin [40]:

$$
\begin{aligned}
& \frac{\mathrm{d} X_{i}(t)}{\mathrm{d} t}=k_{i}\left(X_{i}^{*}(t)-X_{i}(t)\right) \\
& X_{i}(t)=\frac{m_{i}(t)}{m-\sum_{j=1, j \neq i}^{n} m_{j}}, X_{i}^{*}(t)=\frac{m_{i}^{*}(t)}{m-\sum_{j=1, j \neq i}^{n} m_{j}}
\end{aligned}
$$

where $i$ represents the index of moisture, or mineral content, $m_{i}$ is mass of $i$-th component at time $t, m_{i}^{*}$ is mass of $i$-th component at equilibrium, $m$ is total mass, $k_{i}$ is specific rate constant for variation of $i$-th component.

Equilibrium (4) can be integrated with the following initial condition $(t=0)$ :

$X_{i}(0)=X_{i}^{0}$

The solution is:

$$
X_{i}(t)=X_{i}^{*}+e^{-k_{i} t}\left(X_{i}^{0}-X_{i}^{*}\right)
$$

The assumption was made that the Zugarramurdi and Lupines' model Eq. (7) would predict the moisture and solutes content in the kinetics of pork cubes, including equilibrium solute content during the process.

\section{Experimental design and data analysis}

The experimental data were used for effective diffusivities calculation using Eq. (2). Effective diffusivities of moisture content, minerals ( $\mathrm{Na}, \mathrm{K}, \mathrm{Ca}$ and $\mathrm{Mg}$ ) and sucrose content were calculated considering the diffusive model expressed in Eq. (2), and the estimation of "equilibrium" conditions $\left(x_{e q}\right)$, for certain temperature and sugar beet molasses concentration, using Zugarramurdi and Lupines' model, Eq. (7). After calculation of effective diffusivities values for certain temperature and sugar beet molasses concentration, $3^{2}$ full factorial experimental design ( 3 level-2 parameter) with 9 runs (1 block) was accepted for moisture, minerals and sucrose effective diffusivities presentation (Table 2). It was used to design tests for osmotic treatment of pork cubes considering two factors: sugar beet molasses solution concentrated 60,70 and 80 mass $\%$, and temperature $\left(20,35\right.$ and $\left.50{ }^{\circ} \mathrm{C}\right)$. The considered dependent variables were the effective diffusivity of water $\left(D_{w}\right)$, the effective diffusivity of sucrose $\left(D_{\text {suc }}\right)$ and effective diffusivity of minerals $\left(D_{\mathrm{Na}}, D_{\mathrm{K}}, D_{\mathrm{Ca}}\right.$ and $\left.D_{\mathrm{Mg}}\right)$.

The following second order polynomial (SOP) model was fitted to the data. Six models of the following form were developed to relate four responses $(\mathrm{Y})$ and three process variables $(X)$ :

$$
Y_{k}=\beta_{k 0}+\sum_{i=1}^{2} \beta_{k i} X_{i}+\sum_{i=1}^{2} \beta_{k i i} x_{i}^{2}+\beta_{k 12} X_{1} x_{2}, k=1-6
$$

where: $\beta_{k n}$ are constant regression coefficients; $Y$, either $D_{w}\left(Y_{1}\right), D_{\text {suc }}\left(Y_{2}\right), D_{\mathrm{Na}}\left(Y_{3}\right), D_{\mathrm{K}}\left(Y_{4}\right), D_{\mathrm{Ca}}\left(Y_{5}\right)$ or $D_{\mathrm{Mg}}\left(Y_{6}\right)$; $X_{1}$ osmotic temperature; $X_{2}$ solution concentration.

Descriptive statistical analyses for calculating the means and the standard error of the mean were performed using MicroSoft Excel 2007 software. All obtained results were expressed as the mean \pm standard deviation (SD). Regression analysis and analysis of variance (ANOVA) tests for lack of fit, determination of the regression coefficients and generation of contour plots were performed, using StatSoft Statistica 10 software (Statsoft Inc., Tulsa, OK, USA) [41].

The response variables $Y$ were calculated by multiple regressions, and response surface equations were calculated using a definitive model which considered only the influence of significant factors $(p<0.05)$. The response surfaces were drawn by plotting $Y$ as a function of two factor variables, molasses concentration and immersion temperature.

\section{RESULTS AND DISCUSSION}

Obtained results are presented in Table 1.

\section{Water loss and solute uptake}

At the beginning of osmotic process there is an initially high rate of water loss and a quick incurporation of solutes, followed by a slower rate of water loss and solute uptake in the later stages of the process, Table 1. During osmotic treatment of pork cubes, the moisture content ( $x_{w} ; \mathrm{g}$ water per $\mathrm{g}$ of dry solids), sucrose content ( $x_{\text {suc }} ; g$ per $g$ of sample) and mineral content $\left(x_{\mathrm{Na}}, x_{\mathrm{Ca}}, x_{\mathrm{K}}, x_{\mathrm{Mg}}, \mathrm{mg}\right.$ per $\mathrm{g}$ of sample) were experimentally determined in samples at different immersion times for all of the experiments. Moisture and solute contents at equilibrium conditions were determined using Zugarramurdi and Lupines' model, Eq. (7), and are given in Table 2. Zugarramurdi and Lupines' equation proved to be suitable for modeling water removal, sucrose and minerals uptake, as the determination coefficients were above 0.98 for all treatments (Table 2).

\section{Effective diffusivities of water, sucrose and minerals}

The effective diffusivities at any given set of conditions were calculated using non-linear regression analysis from Eq. (2). It is generally assumed that diffusion occurs at a constant rate under the influence of a uniform moisture gradient. However, this does not appear to be true in biological materials, especially 
Table 1. Changes in water loss and solute uptake during osmotic treatment of pork cubes

\begin{tabular}{|c|c|c|c|c|c|c|c|c|}
\hline \multirow{2}{*}{$\begin{array}{l}\text { Immersion } \\
\text { time, } \mathrm{h}\end{array}$} & \multirow{2}{*}{$\begin{array}{l}\text { Temp. } \\
{ }^{\circ} \mathrm{C}\end{array}$} & \multirow{2}{*}{$\begin{array}{c}\text { Solution } \\
\text { concentration, \% }\end{array}$} & \multirow{2}{*}{$\begin{array}{c}\text { Water loss } \\
\%\end{array}$} & \multicolumn{5}{|c|}{ Solid gain, mg/g } \\
\hline & & & & $\mathrm{Na}$ & $\mathrm{K}$ & $\mathrm{Ca}$ & $\mathrm{Mg}$ & Sucrose \\
\hline 1 & 20 & 80 & 0.22 & 174.01 & 502.71 & 45.28 & 19.23 & 4.80 \\
\hline 3 & 20 & 80 & 0.40 & 284.68 & 822.41 & 74.08 & 31.46 & 7.85 \\
\hline 5 & 20 & 80 & 0.47 & 348.19 & 1005.88 & 90.61 & 38.48 & 9.60 \\
\hline 1 & 20 & 60 & 0.24 & 227.11 & 656.09 & 59.10 & 25.10 & 6.26 \\
\hline 3 & 20 & 60 & 0.38 & 321.43 & 928.57 & 83.65 & 35.53 & 8.86 \\
\hline 5 & 20 & 60 & 0.42 & 368.59 & 1064.81 & 95.92 & 40.74 & 10.16 \\
\hline 1 & 20 & 70 & 0.23 & 172.43 & 498.14 & 44.87 & 19.06 & 4.75 \\
\hline 3 & 20 & 70 & 0.39 & 274.93 & 794.23 & 71.55 & 30.39 & 7.58 \\
\hline 5 & 20 & 70 & 0.45 & 330.26 & 954.08 & 85.94 & 36.50 & 9.11 \\
\hline 1 & 35 & 80 & 0.29 & 247.34 & 714.55 & 64.37 & 27.34 & 6.82 \\
\hline 3 & 35 & 80 & 0.46 & 350.01 & 1011.13 & 91.08 & 38.69 & 9.65 \\
\hline 5 & 35 & 80 & 0.52 & 405.51 & 1171.49 & 105.53 & 44.82 & 11.18 \\
\hline 1 & 35 & 60 & 0.28 & 247.67 & 715.48 & 64.45 & 27.37 & 6.83 \\
\hline 3 & 35 & 60 & 0.41 & 333.98 & 964.84 & 86.91 & 36.91 & 9.21 \\
\hline 5 & 35 & 60 & 0.44 & 373.14 & 1077.96 & 97.10 & 41.24 & 10.29 \\
\hline 1 & 35 & 70 & 0.29 & 219.38 & 633.75 & 57.09 & 24.25 & 6.05 \\
\hline 3 & 35 & 70 & 0.44 & 313.87 & 906.73 & 81.68 & 34.69 & 8.65 \\
\hline 5 & 35 & 70 & 0.48 & 361.20 & 1043.46 & 94.00 & 39.92 & 9.96 \\
\hline 1 & 50 & 80 & 0.38 & 352.84 & 1019.32 & 91.82 & 39.00 & 9.73 \\
\hline 3 & 50 & 80 & 0.54 & 447.51 & 1292.80 & 116.46 & 49.46 & 12.34 \\
\hline 5 & 50 & 80 & 0.59 & 495.01 & 1430.03 & 128.82 & 54.71 & 13.65 \\
\hline 1 & 50 & 60 & 0.34 & 300.39 & 867.81 & 78.17 & 33.20 & 8.28 \\
\hline 3 & 50 & 60 & 0.47 & 378.71 & 1094.05 & 98.55 & 41.86 & 10.44 \\
\hline 5 & 50 & 60 & 0.49 & 409.86 & 1184.05 & 106.66 & 45.30 & 11.30 \\
\hline 1 & 50 & 70 & 0.36 & 298.49 & 862.31 & 77.68 & 32.99 & 8.23 \\
\hline 3 & 50 & 70 & 0.51 & 384.98 & 1112.16 & 100.18 & 42.55 & 10.62 \\
\hline 5 & 50 & 70 & 0.54 & 424.31 & 1225.78 & 110.42 & 46.90 & 11.70 \\
\hline
\end{tabular}

Table 2. Parameters of Zugarramurdi and Lupin's model fitted to experimental data

\begin{tabular}{|c|c|c|c|c|c|c|c|c|c|c|c|c|c|}
\hline \multirow[t]{2}{*}{ Temp., ${ }^{\circ} \mathrm{C}$} & \multirow[t]{2}{*}{ Solution conc., $\%$} & \multicolumn{2}{|c|}{$W L$} & \multicolumn{2}{|c|}{$X_{\mathrm{Na}}$} & \multicolumn{2}{|c|}{$X_{\mathrm{K}}$} & \multicolumn{2}{|c|}{$X_{\mathrm{Ca}}$} & \multicolumn{2}{|c|}{$X_{\mathrm{Mg}}$} & \multicolumn{2}{|c|}{$X_{\text {Sucrose }}$} \\
\hline & & $x_{\infty}^{W L}$ & $r^{2}$ & $x_{\infty}^{\mathrm{Na}}$ & $r^{2}$ & $x_{\infty}^{K}$ & $r^{2}$ & $x_{\infty}^{C a}$ & $r^{2}$ & $x_{\infty}^{M g}$ & $r^{2}$ & $x_{\infty}^{\text {Suc. }}$ & $r^{2}$ \\
\hline 20 & 80 & 0.65 & 0.998 & 479.03 & 0.998 & 1490.72 & 0.997 & 121.27 & 0.993 & 37.80 & 0.915 & 12.93 & 0.991 \\
\hline 20 & 60 & 0.59 & 0.997 & 369.61 & 0.997 & 1067.75 & 0.995 & 96.18 & 0.993 & 40.85 & 0.940 & 10.19 & 0.996 \\
\hline 20 & 70 & 0.51 & 0.994 & 413.60 & 0.999 & 1239.10 & 0.998 & 108.65 & 0.995 & 35.00 & 0.993 & 11.38 & 0.994 \\
\hline 35 & 80 & 0.67 & 0.996 & 465.03 & 0.993 & 1348.58 & 0.998 & 124.10 & 0.994 & 43.21 & 0.953 & 12.93 & 0.991 \\
\hline 35 & 60 & 0.58 & 0.992 & 386.08 & 0.999 & 1096.43 & 0.995 & 105.77 & 0.996 & 41.73 & 0.993 & 10.87 & 0.994 \\
\hline 35 & 70 & 0.54 & 0.999 & 386.46 & 0.997 & 1116.45 & 0.994 & 100.57 & 0.991 & 42.71 & 0.908 & 10.66 & 0.998 \\
\hline 50 & 80 & 0.68 & 0.997 & 524.29 & 0.994 & 1514.61 & 0.999 & 136.44 & 0.996 & 66.99 & 0.989 & 14.46 & 0.995 \\
\hline 50 & 60 & 0.62 & 0.998 & 406.63 & 0.997 & 1174.71 & 0.996 & 111.46 & 0.993 & 180.11 & 0.998 & 11.33 & 0.993 \\
\hline 50 & 70 & 0.54 & 0.999 & 401.91 & 0.996 & 1161.06 & 0.995 & 104.59 & 0.991 & 44.42 & 0.994 & 11.08 & 0.999 \\
\hline
\end{tabular}

after the initial stages of the process, as the physical structure of the material begins to change as the osmotic treatment continues. A non-uniform moisture gradient is developed over the course of osmotic treatment and the effective diffusivity changes with geometrical position of specific point inside the material, and time duration of treatment [14]. In meat, $D_{w}$, generally, shows a decreasing trend over time because of the shrinkage phenomenon [42]. Thus, it is assumed that in meat materials $D_{w}$ does not show a pseudo linear correlation with time, as was also reported by Rastogi et al. [14].

Values of effective diffusivity of water, sucrose and minerals at different temperatures and concentrations 
Table 3. Average effective diffusivities of water, sucrose and minerals $\left(10^{10} / \mathrm{m}^{2} \cdot \mathrm{s}^{-1}\right)$ during osmotic treatment of pork

\begin{tabular}{lccccccc}
\hline Temp., ${ }^{\circ} \mathrm{C}$ & Solution conc., $\%$. & $D_{w}$ & $D_{\mathrm{Na}}$ & $D_{\mathrm{K}}$ & $D_{\mathrm{Ca}}$ & $D_{\mathrm{Mg}}$ & $D_{\text {Suc. }}$ \\
\hline 20 & 80 & 6.92 & 5.08 & 4.89 & 5.35 & 2.72 & 5.22 \\
20 & 60 & 7.15 & 5.21 & 5.08 & 5.52 & 2.89 & 5.38 \\
20 & 70 & 7.39 & 5.50 & 5.28 & 5.64 & 3.29 & 5.54 \\
35 & 80 & 7.28 & 5.47 & 5.24 & 5.54 & 3.27 & 5.44 \\
35 & 60 & 7.46 & 5.52 & 5.43 & 5.78 & 3.55 & 5.65 \\
35 & 70 & 7.64 & 5.73 & 5.64 & 5.96 & 4.07 & 5.86 \\
50 & 80 & 7.80 & 6.14 & 5.83 & 5.83 & 4.74 & 5.80 \\
50 & 60 & 7.93 & 6.11 & 6.03 & 6.14 & 5.14 & 6.06 \\
50 & 70 & 8.06 & 6.24 & 6.25 & 6.39 & 5.77 & 6.32 \\
\hline
\end{tabular}

of the osmotic solution are presented in Table 3. These results are in agreement with fundamental theories which state that mass diffusivity strongly depends on the temperature, pressure, and on the components involved. Many investigations require the effective diffusivity to be determined at a range of precise temperatures. Frequently, the relationship between effective diffusivity and temperature follows a first order rate process described by an Arrhenius relationship, Eq. (2).

Several authors have made important model studies on the diffusion coefficients of sodium chloride and other solutes in meat $[13,23,24,43]$. The diffusion coefficient is suggested to be affected by changes in $\mathrm{Na}$ concentration, swelling and degree of treatment [23].

Table 4 presents the analysis of perturbation caused by temperature and concentration.

The regression coefficients for the six diffusive models, obtained by the fitting of experimental data to Eqs. (1) and (2), using Eq. (3), are presented in Table 4. These models were obtained considering only the influence of significant factors $(p<0.05)$, thus some insignificant interaction parameters are absent in the regression equations.

The determination coefficients $\left(r^{2}\right)$ for $D_{w}, D_{\mathrm{Suc}}, D_{\mathrm{Na}}$. $D_{\mathrm{K}}, D_{\mathrm{Ca}}$ and $D_{\mathrm{Mg}}$. models were 0.993, 0.998, 0.999, $0.992,0.999$ and 0.998 , respectively. The average error between the predicted values and experimental values (calculated by Eq. (2)) were below $10 \%$. According to Andrade et al. [28], values of average error below $10 \%$ indicate an adequate fit for practical purposes. To verify the significance of the models, analysis of variance (ANOVA) was conducted and the results indicate that all models were significant with minor lack of fit, suggesting they adequately represent the relationship between responses and factors.

For $D_{w}$ calculation, only interactions between temperature and concentration, and quadratic term of concentration were not significant at $p<0.05$ level. These two independent variables positively affect $D_{w}$. The linear effect of temperature mostly influenced $D_{w}$ calculation, followed by the linear effect of molasses concentration. Similarly, it was verified in the literature that $D_{w}$ is dependent on the temperature, the osmotic solution concentration (using different sugars - sucrose, glucose, fructose, maltodextrin and sorbitol), and on the combination of both parameters for the osmotic treatment $[25,27]$. These researchers modeled $D_{w}$ calculation, using non-linear regression and found an equation much alike to the equation determined in this study (Table 4).

Figure 1 presents response surfaces for $D_{w}$, valid for temperatures ranging from 20 to $50{ }^{\circ} \mathrm{C}$, sugar beet concentrations between 60 and $80 \%$. Figure 1 shows that the influence of temperature on $D_{w}$ is stronger than the influence of molasses concentrations. It is also possible to observe the quadratic effect of these variables and the effect of the interaction between temperature and concentration on $D_{w}$ calculation. Higher values of $D_{w}$ were obtained at temperatures between 45 and $50{ }^{\circ} \mathrm{C}$, and molasses concentrations from 75 to $80 \%$. Experiment 9 was performed in these operating conditions, and it showed the highest values for the effective diffusivity of water (Table 3 ).

In this study, obtained results for effective diffusivity of water are in the range of $6.92 \times 10^{-10}-8.06 \times 10^{-10}$ $\mathrm{m}^{2} \cdot \mathrm{s}^{-1}$. The effective diffusivities of water in shark filets during brining, found by Mujaffar \& Sankat [18], were between $0.17 \times 10^{-9}$ and $0.24 \times 10^{-9} \mathrm{~m}^{2} \cdot \mathrm{s}^{-1}$, at temperatures between $20-50{ }^{\circ} \mathrm{C}$, in $\mathrm{NaCl}$ solution. The differences between the results of this study and the results found in the literature could be explained by the use of different types of materials. Another reason for this difference is the use of a sugar beet molasses solution during dehydration process. The presence of the different nutrients in the osmotic solution affects the mechanism involved in the simultaneous flows of water removal and solute penetration and, consequently, affects the diffusivity values.

Table 4 and Fig. 1 show that the influence of temperature on $D_{\text {suc. }}$ is stronger than the influence of molasses concentrations. Higher values of $D_{\text {suc. }}$ were obtained at higher temperatures and higher molasses concentrations. The effective diffusivity of sucrose in 
Table 4. Analysis of perturbation of response variables $\left(D_{w} . D_{N a} . D_{K} . D_{C a} . D_{M g} . D_{S u c .}\right) \times 10^{10}\left(m^{2} \cdot s^{-1}\right)$ caused by changes in osmotic temperature and solution concentration; ${ }^{*}-$ significant at $p<0.05$ level, $95 \%$ confidence limit

\begin{tabular}{|c|c|c|c|c|c|c|c|}
\hline$D$ & Source & Effect & $t(3)$ & $p$ & -95\% Conf. lim. & +95\% Conf. lim. & Reg. coeff. \\
\hline \multirow[t]{6}{*}{$D_{w}$} & Mean/Interc. ${ }^{*}$ & $2.995 \pm 0.014$ & 207.702 & $<0.01$ & 2.949 & 3.040 & $2.995 \pm 0.014$ \\
\hline & Temp. lin. ${ }^{*}$ & $0.307 \pm 0.016$ & 19.410 & $<0.01$ & 0.256 & 0.357 & $0.153 \pm 0.008$ \\
\hline & Temp. quad. & $0.012 \pm 0.027$ & 0.424 & 0.70 & -0.075 & 0.099 & $0.006 \pm 0.014$ \\
\hline & Conc. lin. ${ }^{*}$ & $0.137 \pm 0.016$ & 8.666 & $<0.01$ & 0.087 & 0.187 & $0.068 \pm 0.008$ \\
\hline & Conc. quad. & $0.006 \pm 0.027$ & 0.236 & 0.83 & -0.081 & 0.094 & - \\
\hline & Temp. x Conc. & $-0.037 \pm 0.019$ & -1.907 & 0.15 & -0.098 & 0.025 & - \\
\hline \multirow[t]{6}{*}{$\mathrm{D}_{\mathrm{Na}}$} & Mean/Interc. ${ }^{*}$ & $2.214 \pm 0.010$ & 228.994 & $<0.01$ & 2.184 & 2.245 & $2.214 \pm 0.010$ \\
\hline & Temp. lin. ${ }^{*}$ & $0.355 \pm 0.011$ & 33.479 & $<0.01$ & 0.321 & 0.388 & $0.177 \pm 0.005$ \\
\hline & Temp. quad. & $0.109 \pm 0.018$ & 5.955 & 0.01 & 0.051 & 0.168 & $0.055 \pm 0.009$ \\
\hline & Conc. lin. ${ }^{*}$ & $0.114 \pm 0.011$ & 10.794 & $<0.01$ & 0.081 & 0.148 & $0.057 \pm 0.005$ \\
\hline & Conc. quad. & $0.047 \pm 0.018$ & 2.584 & 0.08 & -0.011 & 0.106 & $0.024 \pm 0.009$ \\
\hline & Temp. x Conc. & $-0.031 \pm 0.013$ & -2.374 & 0.09 & -0.072 & 0.010 & $-0.015 \pm 0.006$ \\
\hline \multirow[t]{6}{*}{$D_{K}$} & Mean/Interc. ${ }^{*}$ & $2.157 \pm 0.004$ & 534.840 & $<0.01$ & 2.144 & 2.170 & $2.157 \pm 0.004$ \\
\hline & Temp. lin. ${ }^{*}$ & $0.385 \pm 0.004$ & 87.251 & $<0.01$ & 0.371 & 0.400 & $0.193 \pm 0.002$ \\
\hline & Temp. quad. & $0.106 \pm 0.008$ & 13.796 & $<0.01$ & 0.081 & 0.130 & $0.053 \pm 0.004$ \\
\hline & Conc. lin. ${ }^{*}$ & $0.154 \pm 0.004$ & 34.770 & $<0.01$ & 0.140 & 0.168 & $0.077 \pm 0.002$ \\
\hline & Conc. quad. ${ }^{*}$ & $0.019 \pm 0.008$ & 2.457 & 0.09 & -0.006 & 0.043 & $0.009 \pm 0.004$ \\
\hline & Temp. x Conc. & $0.002 \pm 0.005$ & 0.365 & 0.74 & -0.015 & 0.019 & - \\
\hline \multirow[t]{6}{*}{$\mathrm{D}_{\mathrm{Ca}}$} & Mean/Interc. ${ }^{*}$ & $2.302 \pm 0.014$ & 167.602 & $<0.01$ & 2.258 & 2.346 & $2.302 \pm 0.014$ \\
\hline & Temp. lin. ${ }^{*}$ & $0.249 \pm 0.015$ & 16.544 & $<0.01$ & 0.201 & 0.297 & $0.124 \pm 0.008$ \\
\hline & Temp. quad. & $0.033 \pm 0.026$ & 1.259 & 0.30 & -0.050 & 0.116 & - \\
\hline & Conc. lin. ${ }^{*}$ & $0.162 \pm 0.015$ & 10.791 & $<0.01$ & 0.114 & 0.210 & $0.081 \pm 0.008$ \\
\hline & Conc. quad. & $-0.026 \pm 0.006$ & -5.207 & 0.05 & -0.038 & 0.080 & $-0.013 \pm 0.003$ \\
\hline & Temp. x Conc. & $0.039 \pm 0.018$ & 2.125 & 0.12 & -0.019 & 0.098 & - \\
\hline \multirow[t]{6}{*}{$\mathrm{D}_{\mathrm{Mg}}$} & Mean/Interc. & $1.420 \pm 0.005$ & 274.093 & $<0.01$ & 1.403 & 1.436 & $1.420 \pm 0.005$ \\
\hline & Temp. lin. ${ }^{*}$ & $0.905 \pm 0.006$ & 159.562 & $<0.01$ & 0.887 & 0.923 & $0.453 \pm 0.003$ \\
\hline & Temp. quad. & $0.380 \pm 0.010$ & 38.700 & $<0.01$ & 0.349 & 0.412 & $0.190 \pm 0.005$ \\
\hline & Conc. lin. ${ }^{*}$ & $0.322 \pm 0.006$ & 56.777 & $<0.01$ & 0.304 & 0.340 & $0.161 \pm 0.003$ \\
\hline & Conc. quad. ${ }^{*}$ & $0.098 \pm 0.010$ & 9.969 & $<0.01$ & 0.067 & 0.129 & $0.049 \pm 0.005$ \\
\hline & Temp. x Conc. ${ }^{*}$ & $0.079 \pm 0.007$ & 11.336 & $<0.01$ & 0.057 & 0.101 & $0.039 \pm 0.003$ \\
\hline \multirow[t]{6}{*}{$\mathrm{D}_{\text {Suc. }}$} & Mean/Interc. ${ }^{*}$ & $2.269 \pm 0.008$ & 280.026 & $<0.01$ & 2.243 & 2.295 & $2.269 \pm 0.008$ \\
\hline & Temp. lin. & $0.272 \pm 0.009$ & 30.671 & $<0.01$ & 0.244 & 0.300 & $0.136 \pm 0.004$ \\
\hline & Temp. quad. & $0.010 \pm 0.015$ & 0.673 & 0.55 & -0.039 & 0.059 & $0.005 \pm 0.008$ \\
\hline & Conc. lin. ${ }^{*}$ & $0.157 \pm 0.009$ & 17.718 & $<0.01$ & 0.129 & 0.186 & $0.079 \pm 0.004$ \\
\hline & Conc. quad. & $-0.001 \pm 0.015$ & -0.051 & 0.96 & -0.050 & 0.048 & - \\
\hline & Temp. x Conc. ${ }^{*}$ & $0.031 \pm 0.011$ & 2.841 & 0.07 & -0.004 & 0.065 & $0.015 \pm 0.005$ \\
\hline
\end{tabular}

pork cubes was found to be in the range of $5.22 \times 10^{-10}$ $-6.32 \times 10^{-10} \mathrm{~m}^{2} \cdot \mathrm{s}^{-1}$.

The effective diffusivity of $\mathrm{Na}$ in pork cubes, obtained in this study, was estimated and values between $5.08 \times 10^{-10}-6.24 \times 10^{-10} \mathrm{~m}^{2} \cdot \mathrm{s}^{-1}$ were found (Table 3), and it was compared with other studies. Schmidt et al. [26] investigated osmotic treatment in chicken breast cuts, at $5{ }^{\circ} \mathrm{C}$, under stirring conditions, in $\mathrm{NaCl}$ solutions, between 0 and $20 \%$. Obtained effective diffusivities of Na were between $2.5 \times 10^{-10}$ and $2.8 \times 10^{-10}$ $\mathrm{m}^{2} \cdot \mathrm{s}^{-1}$. Gravier et al. [24] used $\mathrm{NaCl}$ solutions between 30 and $200 \mathrm{~g} / \mathrm{L}$ for osmotic treatment of pork, and the obtained effective diffusivities ranged between $0.6 \times 10^{-10}$ and $5.0 \times 10^{-10} \mathrm{~m}^{2} \cdot \mathrm{s}^{-1}$. Figure 1 and Table 4 show that the influence of temperature on $D_{N a}$. is stronger than the influence of molasses concentrations. Higher values of $D_{N a}$. were obtained using higher temperatures and higher molasses concentrations.

The results shown in Fig.1 and Table 4 indicate that the influence of temperature is stronger than the impact of molasses concentration for $D_{K}, D_{C a}$ and $D_{M g}$ calculation. Higher effective diffusion values were obtained at higher temperatures and higher molasses concentrations. The effective diffusivities for $\mathrm{K}, \mathrm{Ca}$ and 

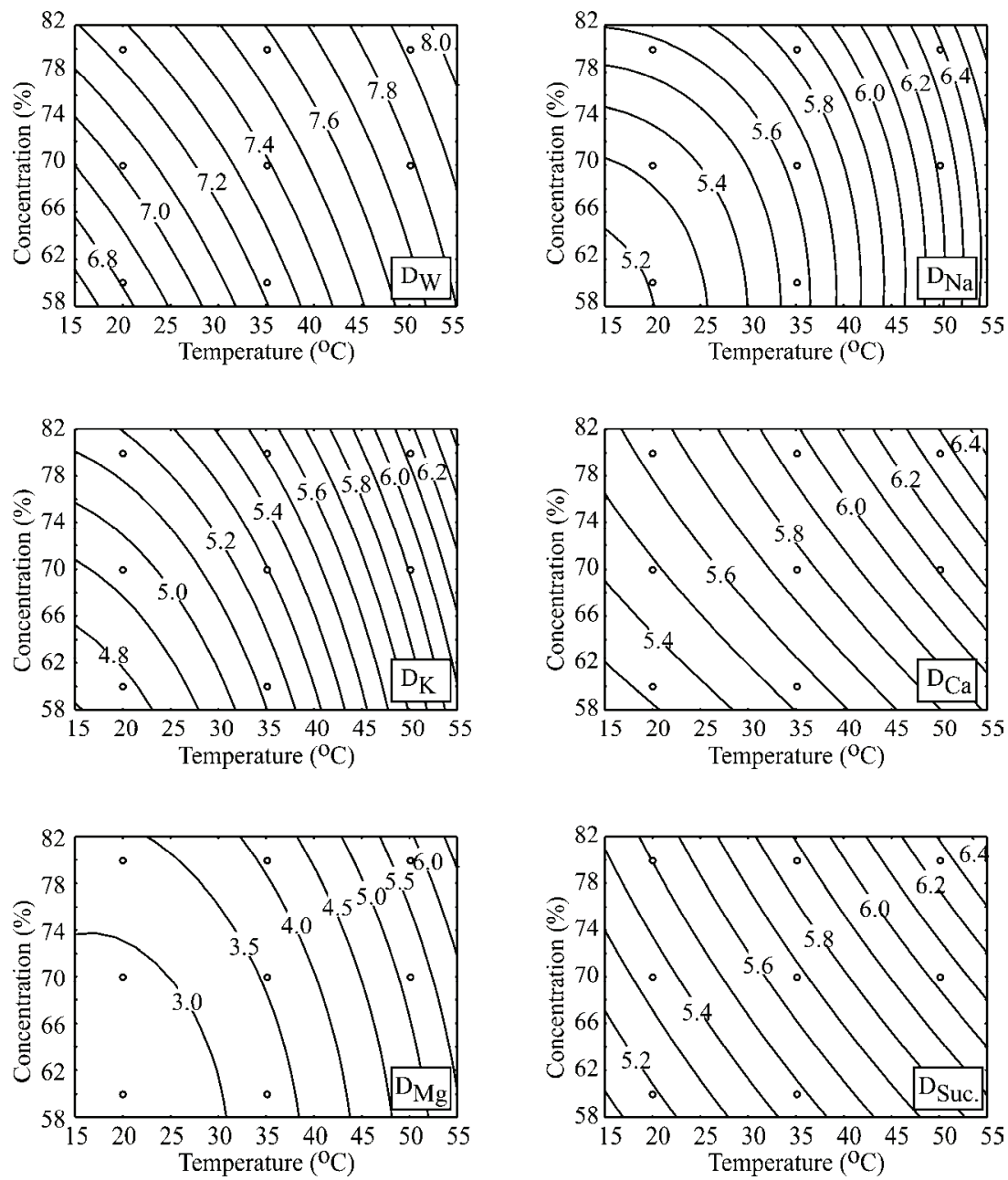

Figure 1. Response surface for effective diffusivity of water, $\mathrm{Na}, \mathrm{K}, \mathrm{Ca} \mathrm{Mg}$ and sucrose as a function of temperature and molasses concentrations $\left(\times 10^{-10} \mathrm{~m}^{2} \cdot \mathrm{s}^{-1}\right)$.

$\mathrm{Mg}$ in meat cubes were estimated, and values between $4.89 \times 10^{-10}$ and $6.25 \times 10^{-10}, 5.35 \times 10^{-10}$ and $6.39 \times 10^{-10}$ and $2.72 \times 10^{-10}$ and $5.77 \times 10^{-10} \mathrm{~m}^{2} \cdot \mathrm{s}^{-1}$ were obtained. Due to the lack of data in the literature, presented results could not be compared.

The differences between the results of this study and the results found in the literature can be explained by the use of different cultivars of pork cubes, and also with different degrees of maturation. Another reason for these differences is the use of sugar beet molasses solution. The presence of the different minerals in the osmotic solution affects the mechanism involved in the simultaneous flows of water removal and solute penetration, and, consequently, affects the diffusivities values.

\section{CONCLUSIONS}

During dehydration experiments of pork in sugar beet molasses solution, performed at different immersion times (1, 3 and $5 \mathrm{~h}$ ), sugar beet molasses concentrations (60, 70 and $80 \%)$ and temperatures (20, 35 and
$50{ }^{\circ} \mathrm{C}$ ), equilibrium moisture content decreased with the temperature rise, while equilibrium content of observed minerals increased with the temperature enhancement. Zugarramurdi and Lupin's model was used for equilibrium values evaluation, and coefficients of determination showed good fitting capabilities.

Fick's unsteady-state diffusion equation has shown to be suitable for determining the mass effective diffusivity of water and solutes in pork cubes. The temperature and osmotic solution composition showed significant effects on all the responses studied. Increases in temperature, and/or molasses concentration led to higher effective diffusivity of water. Effective diffusivities of sucrose were higher at higher temperatures and molasses concentrations. For the above conditions of osmotic treatment, the effective diffusivity of water was found to be in the range of $6.92 \times 10^{-10}$ and $8.06 \times 10^{-10} \mathrm{~m}^{2} \cdot \mathrm{s}^{-1}$. The sucrose effective diffusivity was between $6.39 \times 10^{-10}$ and $8.25 \times 10^{-10} \mathrm{~m}^{2} \mathrm{~s}^{-1}$, while diffusivities $\left(\mathrm{m}^{2} \mathrm{~s}^{-1}\right)$ for minerals were in the range $6.34 \times 10^{-10}-8.82 \times 10^{-10}$ for $\mathrm{Na}, 6.27 \times 10^{-10}-7.43 \times 10^{-10}$ for $\mathrm{K}, 6.44 \times 10^{-10}-8.94 \times 10^{-10}$ for $\mathrm{Ca}$ and $3.47 \times 10^{-10}$ 
$-5.66 \times 10^{-10}$ for $\mathrm{Mg}$. Second order polynomial models fitted the effective diffusion data well.

\section{Acknowledgements}

This work was supported by the Ministry of Education, Science and Technological Development of the Republic of Serbia, Grant: TR 31055, for 2011-2014 project period.

\section{REFERENCES}

[1] J.M. Barat, M. Aliño, A. Fuentes, R. Grau, J.B. Romero, Measurement of swelling pressure in pork meat brining, J. Food Eng. 93 (2009) 108-113.

[2] A. Collignan, P. Bohuon, F. Deumier, I. Poligné, Osmotic treatment of fish and meat products, J. Food Eng. 49 (2001) 153-162.

[3] F.C.Schmidt, B.A.M. Carciofi, J.B. Laurindo, Salting operational diagrams for chicken breast cuts: hydrationdehydration. J. Food Eng. 91 (2008) 36-44.

[4] E. Desmond, Reducing salt: a challenge for the meat industry, Meat Sci. 74 (2006) 188-196.

[5] WHO/FAO (World Health Organization/Food and Agriculture Organisation) Diet, nutrition and the prevention of chronic diseases. WHO Technical Report Series 916. Geneva, World Health Organization, 2003.

[6] M. Aliño, R. Grau, F. Toldrá, E. Blesa, M.J. Pagán, J.M. Barat, Influence of sodium replacement on physicochemical properties of dry-cured loin, Meat Sci. 83 (2009) 423-430.

[7] M. Aliño, R. Grau, F. Toldrá, M.J. Pagán, J.M. Barat, Physicochemical changes in dry cured hams salted with potassium, calcium and magnesium chloride as a partial replacement for sodium chloride, Meat Sci. 86 (2010) 331-336

[8] M. Armenteros, M.C. Aristoy, J.M. Barat, F. Toldrá, Biochemical changes in dry-cured loins salted with partial replacements of $\mathrm{NaCl}$ by $\mathrm{KCl}$, Food Chem. 117 (2009) 627-633.

[9] M. Aliño, R. Grau, A. Fernández-Sánchez, A. Arnold, J.M. Barat, Influence of brine concentration on swelling pressure of pork meat throughout salting, Meat Sci. 86 (2010) 600-606.

[10] M. Armenteros, M.C. Aristoy, J.M. Barat, F. Toldrá, Biochemical and sensory properties of dry-cured loins as affected by partial replacement of sodium by potassium, calcium and magnesium J. Agr. Food Chem. 57 (2009) 9699-9705.

[11] E. Blesa, M. Aliño, J.M. Barat, R. Grau, F. Toldrá, M.J. Pagán, Microbiology and physico-chemical changes of dry-cured ham during the post-salting stage as affected by partial replacement of $\mathrm{NaCl}$ by other salts, Meat Sci. 78 (2008) 135-142.

[12] J. Gelabert, P. Gou, L. Guerrero, J. Arnau, Effect of sodium chloride replacement on some characteristics of fermented sausages, Meat Sci. 65 (2003) 833-839.

[13] A. Costa-Corredor, I. Muñoz, J. Arnau, P. Gou, Ion uptakes and diffusivities in pork meat brine-salted with
$\mathrm{NaCl}$ and K-lactate, LWT - Food Sci. Technol. 43 (2010) 1226-1233.

[14] N.K. Rastogi \& K.S.M.S. Raghavarao, K. Niranjan, D. Knorr, Recent developments in osmotic dehydration: methods to enhance mass transfer. Trends Food Sci. Tech. 13 (2002) 48-59.

[15] E. Spiazzi, R. Mascheroni, Mass transfer model for osmotic dehydration of fruits and vegetables. I. Development of the simulation model. J. Food Eng. 34 (1997) 387-410.

[16] A. Chiralt, P. Fito, J.M. Barat, A. Andrés, GonzálezMartínez, C., I. Escriche, M.M. Camacho, Use of vacuum impregnation in food salting process. J. Food Eng. 49 (2001) 141-151.

[17] V.R.N. Telis, P.F. Romanelli, A.L.Gabas, J.T. Romero, Salting kinetics and salt diffusivities in farmed caiman muscle. Pesqui. Agropecu. Bras. 38 (2003) 529-535.

[18] S. Mujaffar, C. Sankat, The mathematical modeling of the osmotic dehydration of shark fillets at different brine temperatures, Int. J. Food Sci. Tech. 40 (2005) $1-12$.

[19] G. Volpato, E.M.Z. Michielin, S.R.S. Ferreira, J.C.C. Petrus, Kinetics of the diffusion of sodium chloride in chicken breast (Pectoralis major) during curing, J. Food Eng. 79 (2007) 779-785.

[20] H. N. Lazarides, V. Gekas, Mavroudis, N. Apparent mass diffusivities in fruit and vegetable tissues undergoing osmotic processing. J. Food Eng. 31 (1997) 315-324.

[21] B. Singh, A. Kumar, A. K. Gupta, Study of mass transfer kinetics and effective diffusivity during osmotic dehydration of carrot cubes, J. Food Eng. 79 (2007) 471-480.

[22] A.S. Pajonk, R. Saurel, J. Andrieu, Experimental study and modeling of effective $\mathrm{NaCl}$ diffusion coefficients values during Emmental cheese brining., J. Food Eng. 60 (2003) 307-313.

[23] C. Vestergaard, J. Risum, J. Adler-Nissen, Na-MRI quantification of sodium and water mobility in pork during brine curing, Meat Sci. 69 (2005) 663-672.

[24] N. Graiver, A. Pinotti, A. Califano, N. Zaritzky, Diffusion of sodium chloride in pork tissue, J. Food Eng. 77 (2006) 910-918.

[25] F. Kaymak-Ertekin, M. Sultanoglu, Modelling of mass transfer during osmotic dehydration of apples, J. Food Eng. 46 (2000) 243-250.

[26] F.C. Schmidt, B.A.M. Carciofi, J.B. Laurindo, Application of diffusive and empirical models to hydration, dehydration, and salt gain during osmotic treatment of chicken breast cuts, J. Food Eng. 91 (2009) 553-559.

[27] A. Ispir, I.T. Togrul, Osmotic dehydration of apricot: kinetics and the effect of process parameters. Chem. Eng. Res. Des. 87 (2009) 166-180.

[28] S.A.C. Andrade, B.B.Neto, A.C. Nóbrega, P.M. Azoubel, N.B. Guerra, Evaluation of water and sucrose diffusion coefficients during osmotic dehydration of jenipapo (Genipa americana L.), J. Food Eng. 78 (2007) 551-555.

[29] A.M. Sereno, R. Moreira, E. Martinez, Mass transfer coefficients during osmotic dehydration of apple single and combined aqueous solution of sugar and salts. J.Food Eng. 47 (2001) 43-49. 
[30] S. Rodrigues, F.A.N. Fernandes, Dehydration of melons in a ternary system followed by air-drying, J. Food Eng. 80 (2007) 678-687.

[31] G. Sacchetti, A. Gianotti, M. Dalla Rosa, Sucrose-salt combined effects on mass transfer kinetics and product acceptability. Study on apple osmotic treatments, J. Food Eng. 49 (2001) 163-173.

[32] P. Bohuon, A. Collignan, G. M. Rios, A.L. Raoult-Wack, Soaking process in ternary liquids: experimental study of mass transport under natural and forced convection, J. Food Eng. 37 (1998) 451-469.

[33] D. Sauvant, J.-M. Perez, G. Tran, Tables de composition et de valeur nutritive des matières premières destinées aux animaux d'élevage: Porcs, volailles, bovins, ovins, caprins, lapins, chevaux, poissons, 2ème édition revue et corrigée. INRA Editions, Versailles, France. 2004.

[34] D. Grbeša, Assessment methods and tables of chemical composition and nutritional value of food (in Croatian), Zagreb: Faculty of Agriculture, University of Zagreb, Croatian Society of Agronomists, 2004, pp. 134-137.

[35] N.M. Mišljenović, G.B. Koprivica, L.L. Pezo, LJ.B. Lević, B.L. Ćurčić, V. S. Filipović, M. R. Nićetin, Optimization of the osmotic dehydration of carrot cubes in sugar beet molasses, Therm. Sci. 16 (2012) 43-52.
[36] L.L. Pezo, B.Lj. Ćurčić, V.S. Filipović, M.R. Nićetin, G.B. Koprivica, N.M. Mišljenović, Lj. B. Lević, Artificial neural network model of pork meat cubes osmotic dehydration, Hem. Ind. 67 (2013) 465-475.

[37] AOAC Official methods of analysis, Association of Official Analytical Chemists, Moisture Content in Plants, Washington, DC, 930.04, 1990.

[38] J. Crank, The mathematics of diffusion, $2^{\text {nd }}$ ed., Clarendon, Oxford, 1975.

[39] N.K. Rastogi, K.S.M.S. Raghavarao, Water and solute diffusion coefficients of carrot as a function of temperature and concentration during osmotic dehydration, J. Food Eng. 34 (1997) 429-440.

[40] A. Zugarramurdi, H.M. Lupin, A model to explain observed behavior on fish salting. J. Food Sci. 45 (1980) 1305-1311.

[41] Statistica (Data Analysis Software System). 2010. v.10., StatSoft, Inc., Tulsa, OK (www.statsoft.com).

[42] J.M. Barat, S. Rodríguez-Barona, A. Andrés, P. Fito, Influence of increasing brine concentration in the cod salting process, J. Food Sci. 65 (2002) 1922-1925.

[43] C.L. Hansen, F. Van Der Berg, S. Ringgaard, H. StødkildeJørgensen, A.H. Karlsson, Diffusion of $\mathrm{NaCl}$ in meat studied by $1 \mathrm{H}$ and $23 \mathrm{Na}$ magnetic resonance imaging, Meat Sci. 80 (2008) 851-856. 


\section{IZVOD}

\section{PRIVIDNI KOEFICIJENTI DIFUZIJE VODE, SAHAROZE I MINERALA PRI OSMOTSKOM TRETMANU SVINJSKOG MESA U MELASI ŠEĆERNE REPE}

Milica R. Nićetin ${ }^{1}$, Lato L. Pezo ${ }^{2}$, Biljana Lj. Lončar ${ }^{1}$, Vladimir S. Filipović ${ }^{1}$, Danijela Z. Šuput ${ }^{1}$, Snežana Zlatanović ${ }^{2}$, Biljana P. Dojčinović ${ }^{3}$

${ }^{1}$ Univerzitet u Novom Sadu, Tehnološki fakultet, 21000 Novi Sad, Srbija

${ }^{2}$ Univerzitet u Beogradu, Institut za opštu i fizičku hemiju, 11000 Beograd, Srbija

${ }^{3}$ Univerzitet u Beogradu, Institut za hemiju, tehnologiju i metalurgiju, 11000 Beograd, Srbija

(Naučni rad)

Metoda odzivne površine (Response Surface Methodology - RSM) je korišćena pri matematičkom modelovanju i izračunavanju vrednosti prividne (efektivne) difuzije vode, saharoze i minerala tokom osmotskog tretmana kockica svinjskog mesa (M. triceps brachii), na temperaturi 20,35 i $50{ }^{\circ} \mathrm{C}$ i pri koncentracijama osmotskog rastvora (melasa šećerne repe) od 60, 70 i 80 mas.\%. Numeričko rešavanje Fikovog (Fick) zakona o prenosu mase, pri nestacionarnim uslovima, za idealnu kocku je korišćeno za izračunavanje efektivnog koeficijenta difuzije vode, saharoze i minerala ( $\mathrm{Na}, \mathrm{K}, \mathrm{Ca}$ and $\mathrm{Mg}$ ). Sadržaj vlage i minerala je izmeren u tri ponavljanja. Korišćen je model Cuguramurdija (Zugarramurdi) i Lupina (Lupin) za predviđanje ravnotežnih uslova i ispostavilo se da je taj model pogodan za izračunavanje gubitka vlage i priraštaja suve materije tokom procesa osmotskog tretmana. Metoda odzivnih površina, koje se široko koristi za modelovanje i kontrolu procesa u prehrambenoj industriji, a u ovom radu je korišćena za predviđanje efektivnog koeficijenta difuzije vode, saharoze i minerala, pri određenoj temperaturi imerzije i koncentraciji melase šećerne repe. Matematički modeli koji su dobijeni na osnovu eksperimentalnih podataka obrađuju kompleksne nelinearne relacije sa interakcijama između procesnih promenjljivih. Dobijene vrednosti efektivne difuzivnosti $\left(\mathrm{m}^{2} \mathrm{~s}^{-1}\right)$ za vodu bili su u rasponu od $6,95 \times 10^{-10}$ do $8,03 \times 10^{-10}$, za efektivnu difuzivnost saharoze bili su između $6,39 \times 10^{-10}$ i $8,25 \times 10^{-10}$, dok su difuzivnosti za minerale bile u opsezima: $6,34 \times 10^{-10}-8,82 \times 10^{-10}(\mathrm{Na}), 6,27 \times 10^{-10}$ $-7,43 \times 10^{-10}$ (K), $6,44 \times 10^{-10}-8,94 \times 10^{-10}$ (Ca) i $3,47 \times 10^{-10}-5,66 \times 10^{-10}$ (Mg). Korišćenjem razvijenih matematičkih modela dobijene su vrednosti efektivnih koeficijenata difuzije, sa tačnošću izraženom preko koeficijenata determinacije $\left(r^{2}\right)$ za $D_{w}, D_{\mathrm{Suc}}, D_{\mathrm{Na}} . D_{\mathrm{K}}, D_{\mathrm{Ca}}$ i $D_{\mathrm{Mg}}$, i to: 0,$993 ; 0,998 ; 0,999 ; 0,992 ; 0,999$ i 0,998 , redom. Širok opseg procesnih promenljivih veličina razmatranih u formiranju ovih modela, kao i njihova laka implementacija u tabelarnim proračunima, čini ove modele veoma praktičnim za projektovanje i kontrolu procesa.
Ključne reči: Svinjsko meso - Melasa šećerne repe $\bullet$ Osmotski tretman $\bullet$ Difuzija • Prenos mase 